Discrimination against female migrants wearing headscarves

by

Doris WEICHSELBAUMER

Working Paper No. 1609

September 2016

Johannes Kepler University of Linz Department of Economics Altenberger Strasse 69 A-4040 Linz - Auhof, Austria www.econ.jku.at 


\title{
Discrimination against female migrants wearing headscarves
}

\author{
Doris Weichselbaumer \\ Johannes Kepler University Linz \\ doris.weichselbaumer@jku.at \\ JEL classification: C93; J15; J71 \\ Keywords: Discrimination, Muslim religion, Headscarf, Hiring, Experiment
}

\begin{abstract}
Germany is currently experiencing a high influx of Muslim migrants. From a policy perspective, integration of migrants into the labor market is crucial. Hence, a field experiment was conducted that examined the employment chances of females with backgrounds of migration from Muslim countries, and especially of those wearing headscarves. It focused on Turkish migrants, who have constituted a large demographic group in Germany since the 1970s. In the field experiment presented here, job applications for three fictitious female characters with identical qualifications were sent out in response to job advertisements: one applicant had a German name, one a Turkish name, and one had a Turkish name and was wearing a headscarf in the photograph included in the application material. Germany was the ideal location for the experiment as job seekers typically attach their picture to their résumé. High levels of discrimination were found particularly against the migrant wearing a headscarf.
\end{abstract}

I thank Sandra Leitner, Barbara Mühlbacher, Sylvia Sadzinski, Mario Schnalzenberger, Julia Schuster and Sandra Stoll for their excellent research assistance, Sengül Karakoc and members of the "Türkische Gemeinde, Berlin" for their assistance in creating convincing applications, Sigrid Betzelt, Claudia Gather, Monika Huesmann, Gertraude Krell, Friederike Maier, and Rudolf-Winter-Ebmer for their invaluable help in setting up the experiment and/or their helpful advice and comments. This research was funded by the Austrian Science Fund (FWF), National Research Network S103, Austrian Center for Labor Economics and the Analysis of the Welfare State. 


\section{Introduction}

In Western countries, anti-Muslim sentiments and Islamophobia have grown substantially since the beginning of the $21^{\text {st }}$ century. In the aftermath of September 11 , 2001, an increase in Anti-Muslim hate crimes has been noted particularly in the U.S. (ADC-RI 2008; FBI). Also, the U.S. Equal Employment Opportunity Commission has reported a rise in religion-related complaints by Muslims since 2001, which suggests that Muslims feel increasingly discriminated against in employment matters. Negative stereotypes depict Muslims as "religious fanatics, terrorists, hostile, evil, barbaric, wild, backward, disorganized people who mistreat and oppress women" (Ghumman and Jackson 2010, p. 6). Such negative stereotypes can, of course, harm Muslims in their work and social lives.

Islamophobia, however, is not confined to the U.S. but has also become more common in European countries, such as Germany, which this study examines more closely. Most Muslims in Germany are members of immigrant communities, and the majority has a Turkish background. Estimates of the proportion of Muslims in the German population range from $1.9 \%$ to $5 \%$ (Spielhaus 2013). According to a representative survey (Bertelsmann Stiftung 2015) that was published just before the recent influx of Syrian Muslim migrants into Germany, 57\% of Germany's non-Muslims perceived Islam as a threat. $40 \%$ of the respondents said that they did not feel at home in their own country due to the country's purported "Islamization", and $24 \%$ believed that Germany should no longer permit Muslims to immigrate. Prejudice against Muslims has also been documented by the World Values Survey, which routinely asks respondents whom, out of a list of people, they would not like to have as neighbors. In 2006, 24.8\% of Germans were against the idea of Muslims as neighbors (World Values Survey 2006). ${ }^{1}$ Given that other groups do not necessarily trigger such a negative response by Germans (in comparison: "people of a different race", "foreign workers", and "people of a different religion" were rejected by $7.2 \%, 13.3 \%$, and $4.3 \%$ of the respondents, respectively), it appears that Muslims currently constitute a particularly disliked "outgroup" in Germany.

\footnotetext{
${ }^{1}$ The World Values Survey USA included this question for the last time in 1999, when 10.7\% of the USAmerican respondents said that they did not want Muslims as neighbors.
} 
The Muslim headscarf or hijab is particularly controversial. ${ }^{2}$ As Helbling (2014) showed for 6 European countries (one of them Germany), attitudes of non-Muslims are significantly more negative towards the headscarf than towards Muslims in general. While only about one quarter of survey respondents opposed Muslims, nearly $60 \%$ disagreed with the practice of women wearing headscarves. According to another survey, $60 \%$ of Germans support a ban of Muslim headscarves in public places (Van der Noll 2010). Indeed, several European countries have implemented such laws (Byng 2010). In some German federal states, teachers were banned from wearing headscarves in 2003. However, in March 2015 the Constitutional Court in Karlsruhe ruled that an absolute ban is incompatible with religious freedom and unconstitutional.

A number of reasons may be responsible for the particularly strong rejection of the headscarf in comparison to Muslims in general. First, the headscarf is often considered as a symbol not of Islam in general but of Muslim fundamentalism (Shadid and van Koningsveld 2005), which is frequently associated with intolerance and terrorism. Second, the headscarf has been interpreted as a sign of apparent unwillingness on the part of Muslim migrants to integrate, which has been used by the media to claim that national integration policies have failed (Byng 2010). Finally, the headscarf has been considered as an expression of women's oppression and the rejection of gender equality (Shadid and van Koningsveld 2005). Opponents of the headscarf maintain that Muslim women wear it because they are forced to by their parents, by (male) family members or by religious leaders. They argue that the liberal state should not accommodate the cultural traditions of minority groups if these infringe upon women's rights, freedom and autonomy. However, it is debatable whether the headscarf or hijab is in conflict with these values or actually supports them. Many Muslim feminists argue that they wear the headscarf by choice and see it as an empowering practice. Banning the headscarf would then inhibit their autonomy as women. In any case, Westerners rejecting the headscarf as an indicator of the oppression of women may explain some of the observed difference in acceptance of Muslims in general and of the headscarf in particular.

One theoretical framework that is able to analyze dynamics between social groups and may thus help to explain why women wearing the headscarf are especially discriminated against in the labor market is Social Identity Theory. Social Identity

\footnotetext{
${ }^{2}$ The hijab is a veil that Muslim women wear to cover their head and chest.
} 
Theory (e.g., Tajfel 1981) argues that people gain self-esteem by attributing a higher value to their own social group ("ingroup") than to others ("outgroup"). Along this line, Akerlof and Kranton (2000) pointed out that social identity is crucial to our understanding of who should do what job in the economy. For example, men may fear for their male identity if women do the same kind of work as they do. A "distaste" for women (Becker 1971) in male professions and a gender-segregated labor market may be the result. Similarly, non-migrants may feel threatened and fear for their presumed "superiority" if migrants, particularly Muslims, enter their ranks. To prevent this from happening, employers may exclude migrants from their immediate workforce. Especially women wearing headscarves may experience this rejection because they signal a greater identification with the "Muslim outgroup". Social Identity Theory suggests that individuals who identify more strongly with an outgroup are perceived as more "distant" by members of the ingroup. As a result, they suffer from increased levels of discrimination. For example, Derous et al. (2009) found that Dutch and American students evaluated résumés with Arab names more negatively if these signaled a high Arab identification. Also, people whose "stigmas" are visible typically experience more discrimination than others.

\section{Empirical evidence for unfavorable treatment of Muslims}

So far, little research has focused on labor market discrimination against Muslims. ${ }^{3} \mathrm{~A}$ sizeable number of correspondence testing experiments have been conducted to examine discrimination against migrants from Muslim countries, but in most cases these did not explicitly examine the effects of religion. In correspondence testing experiments, fake application letters that signal identical qualifications but different demographic characteristics are sent to companies. If, despite identical qualifications, one applicant is invited for interview more often than the other, this is considered discrimination. Experiments like these have been lauded by the OECD and the National Academies' National Research Council's Committee on National Statistics as "an important and useful means of measuring discrimination" (Blank et al. 2004, p. 7). In the context of

\footnotetext{
${ }^{3}$ Experiments testing discrimination outside the labor market often used a "lost-letter" design and found that finders are more likely to post a lost letter if the addressee was a "local" and not a "Muslim" (e.g., Ahmed 2010). Another design for testing discrimination is to let participants of distinct ethnic affiliations play trust, dictator or ultimatum games with each other (see Fershtman and Gneezy 2001). However, to my knowledge no such experiment has yet been conducted to examine discrimination against Muslims.
} 
discrimination based on migration background in OECD countries, correspondence tests have examined the employment possibilities of migrants from the Middle East and Turkey, and of Arabs, North-Africans and Pakistanis (for an overview see: Rich 2014; Zschirnt and Ruedin 2016) ${ }^{4}$. These studies typically indicated the background of a migrant via the name given in the job application, and documented high levels of discrimination against migrants in most cases. Only a few correspondence tests focused more explicitly on the Muslim religion of migrants and did more than simply assign a common name from a Muslim country to one of the applicants: Adida et al. (2010) as well as Pierné (2013) examined the employment chances of migrants with Muslim and Catholic religious affiliation in France. As a signal of religion they used work and volunteer experiences for Catholic and Muslim organizations in their applicants' résumés. Both studies found that Muslim migrants fared worse than Catholic migrants. Acquisti and Fong (2015) tested the effect of personal information posted online by US American job candidates. In this study, religious affiliation was not signaled through the résumé but through manipulating the "religion" field in a social network profile (Christian, Muslim or no specific denomination) that employers could search for in the web. This manipulation led to significant bias against the Muslim candidate and favoritism for the Christian candidate in Republican but not in Democratic areas.

The effect of wearing a headscarf or a hijab on employment chances has barely been researched so far. In particular, no correspondence study has yet been conducted to test its effect. This is probably due to the fact that in most Western countries, aside from Germany, job seekers do not attach photographs to their job applications. This makes it difficult for the researcher to signal the wearing of a headscarf. Unkelbach et al. (2010) have conducted one of the few laboratory studies that examined the effect of wearing a hijab on personnel decisions. Students from a German university were presented grades and photos of more than hundred applicants with different ethnicities, some of them wearing a hijab. The students were instructed to make quick decisions to reject half of the applicants right away while keeping the rest for in-depth evaluation. Results showed that applicants with a hijab were more likely to be rejected, but also the response latencies differed: Wearing a headscarf sped up negative responses and slowed down positive responses. This implies that participants find it easier to associate women

\footnotetext{
${ }^{4}$ For a broader overview on experimental research concerning labor market discrimination see Bertrand and Duflo (2016) and Neumark (forthcoming).
} 
without a hijab with employability than women who wear a hijab. ${ }^{5}$ For the U.S., Ghumman and Jackson (2008) conducted a web-based experiment with students from a Midwestern university. Participants were shown résumés and pictures of male or female job applicants with different religious identifiers (no religious identifier, Christian, Jewish, Muslim). For women, Muslim religion was indicated by the Muslim headscarf, while a turban was used for Muslim men. Interestingly, while male applicants who wore a Muslim turban received the lowest employability ratings of all groups, women with a Muslim headscarf scored the highest of all groups. ${ }^{6}$ The disadvantage of laboratory experiments, of course, is that their results may not be transferrable into the real world. Participants in the typical laboratory study are often not representative for those making hiring decisions in real life. In particular students who are often participants in laboratory studies may be more liberal than the average personnel manager. Also, participants in the laboratory do not face any consequences of their fictitious employment decisions: for example, they do not have to work with an individual that they indicated to be 'hirable' but who they dislike. As a result, choices in the laboratory may be systematically less discriminatory than in real life. ${ }^{7}$

Experiments, where testers with different demographic backgrounds apply for jobs in person, are called 'audit studies'. Audit studies are conducted in the field, consequently, they more closely resemble real life employment decisions. Because in audit studies employers are not aware that they take part in an experiment they give unbiased responses. Ghumman and Ryan (2013) sent female confederates to the stores of two shopping malls in the U.S. Midwest to ask for job openings. For half of the trials the confederates wore a headscarf. While there was no difference in the likelihood to be told about job openings, the applicants with headscarves were significantly less likely to receive a callback, they were also less often given the possibility to complete a job application. In a similar study, King and Ahmad (2010) did not only examine hiring chances but also interpersonal behavior towards applicants. ${ }^{8}$ In their experiment, differences with respect to job recommendations and job callbacks did not reach

\footnotetext{
${ }^{5}$ In another study Unkelbach et al. (2008) examined the effect of wearing a Muslim turban or hijab in a computer shooting game. Here the authors found that participants shoot more at targets with a Muslim headgear.

${ }^{6}$ In another experiment Ghumman and Jackson (2010) asked Muslim women, some of which wore a hijab, to estimate their chances to receive a job offer - assuming they applied to a given job and held all the necessary qualifications. The authors found that women who wear a hijab had lower expectations of receiving a job offer than those who did not wear a headscarf.

${ }^{7}$ See e.g., List (2011) for the advantages of field experiments.

${ }^{8}$ In this experiment, Muslim attire included not only a black hijab, but also a black abbaya (robe).
} 
statistical significance. However, this may be due to the small sample size. ${ }^{9}$ The authors did identify significant effects concerning differences in interpersonal treatment though: When the testers wore headscarves, interactions with managers were shorter and the testers reported higher levels of negativity received from the potential employer. This result suggests that formal discrimination with respect to job opportunities may only be the tip of the iceberg: a lot of discrimination may occur through personal interaction.

Audit studies are of great interest as they examine job opportunities of disadvantaged groups in the field instead of the laboratory. However, there are severe disadvantages also associated with the method of audit studies (for an overview see Heckman and Siegelman 1993; Heckman 1998). For example, sample sizes of audit studies are necessarily small and often only a few localities are covered. ${ }^{10}$ In contrast, the method of correspondence testing does not only allow collecting larger amounts of data, it can also cover a larger geographical area (e.g., multiple cities of a country). More crucially, because in audit studies job seekers talk to managers in person, it is difficult to avoid a 'confederate bias'. This means that confederates may be inclined to behave in ways that foster discrimination. Experimenters try to avoid this problem by giving the confederates a script to adhere to. Ghumman and Ryan (2013) have even observed and compared confederates' behavior in the different conditions, not finding any significant difference. However, it may be difficult to fully control and assess all aspects of an individual's behavior. In correspondence testing experiments, matching all aspects of an application apart from demographics is not a problem. Furthermore, as letters of applications of individuals are strictly standardized, the automated procedure does not leave any room for a confederate or experimenter bias. Therefore, the method of correspondence testing circumvents the problems typically associated with audit studies (Bertrand and Mullainathan 2004).

\section{Current study}

For the study presented here, a correspondence testing experiment was conducted to investigate not only whether discrimination against female Turkish migrants occurs in Germany, but also whether wearing a headscarf significantly affects female migrants'

\footnotetext{
${ }^{9} 21 \%$ (38\%) of applicants with (without) religious attire were recommended a position, 24\% (35\%) received job callbacks, $\mathrm{N}=81$.

${ }^{10}$ For example, Ghumman and Ryan (2013) observed 112 trials in two shopping malls, King and Ahmad (2010) based their analysis on 81 interactions collected in public shopping areas in the metropolitan D.C area.
} 
employment chances. To indicate a Turkish background - or a lack thereof - first and last names that are common in Turkey (Meryem Öztürk) and Germany (Sandra Bauer), were used in the résumés. Signaling that the applicant wears a headscarf was enabled by the specifics of the German application process: In German-speaking countries, job seekers need to submit a large amount of material to be considered serious applicants (Weichselbaumer 2015). Apart from school reports and personal data (age, marital status), photographs are an integral part of German job applications. This, of course, is in contrast to practices in countries like the U.S. or the U.K. where the attachment of photographs would be considered awkward. Consequently, while in the English speaking context correspondence tests cannot be applied for research questions that require a visual signal, in Germany, photographs can be attached to applications without causing suspicion. ${ }^{11}$ All applications sent in this experiment therefore included photographs of the same person, who was wearing a headscarf in some of the cases (see Figure 1). Three different identities were tested in this experiment: One woman with a German name (bareheaded), one with a Turkish name (bareheaded) and one woman with a Turkish name who wore a headscarf. ${ }^{12}$ For the fabrication of suitable photographs a "model" was hired who equally passed as German as well as Turkish. To ensure that the portrayals of the Turkish women included in the study were realistic, representatives of the Turkish community in Berlin (“Türkische Gemeinde e.V.") were consulted, who helped with the final selection of photographs. A very modern binding of the headscarf was chosen to signal that the applicant was a young, modern woman who could easily fit into a secular environment. Given that her throat was not covered, it was unlikely that she was particularly strict with respect to her religion - let alone a religious radical. By choosing this representation of a Muslim woman, discrimination against her should be minimized.

Another advantage of the large amount of information required in the German setting is that it leaves little ambiguity about an applicant's productivity. This makes statistical discrimination less likely. Phelps (1972) and Arrow (1973) stated that statistical discrimination occurs if information about an individual's productivity is lacking and employers therefore resort to group averages to infer an individual's

\footnotetext{
${ }^{11}$ See Weichselbaumer (forthcoming) for a discussion on the advantages of using photographs in correspondence tests in German-speaking countries.

${ }^{12}$ Of course it could also be interesting to test the employment chances of a German woman without migration background who wears a headscarf and thereby signals she has converted to Islam. However, given the few women that fit this category in real life, this question is of little empirical relevance.
} 
productivity. However, if productivity is indicated by means of the detailed information in an application (examination results, job experience, age, marital status, etc.), as is the case in Germany, the level of ambiguity is low.

Randomized application procedure. Most correspondence testing experiments send multiple applications, and some even mail a whole battery of comparable résumés to one company. However, this may be problematic in certain circumstances. As Weichselbaumer (2015) illustrated, sending multiple applications to one firm can lead to seriously biased results, at least in Germany, because the results of correspondence testing experiments have been widely discussed in Germany's popular media. The method is therefore increasingly well known among personnel managers. Consequently, employers may notice the similarities between fictitious applications, suspect that they are being tested, and present themselves as more minority-friendly than they usually are. The problem is aggravated particularly by the large set of application documents required in Germany. To maintain strict comparability of applicants within the experiment, all résumés, school reports, etc. must be matched. Paired fictitious applications therefore stand out even more from the heterogeneous pool of nonexperimental applications.

To avoid detection, this experiment thus followed Ahmed et al. (2013) and Weichselbaumer (2015) in that only one profile was sent to each firm. This has the advantage that all applications sent can be virtually identical except for the variables of interest. It also allows photographs of the same person to be used for all identities. By showing the same "model" in the same pose in all identities, "beauty" was automatically held constant across ethnic backgrounds. As previous studies have shown, beauty considerably affects applicants' hiring probabilities (Ruffle and Shtudiner 2015; López Bóo et al. 2013; Rooth 2009). The identity of the applicant (German name, Turkish name/no headscarf, Turkish name/headscarf) was randomly assigned to each application by variation of the name and photograph.

Occupations. This study focused on the employment chances of office workers, i.e., secretaries, accountants and chief accountants. Although all of these are office jobs, they vary in terms of status: the job of chief accountant is most highly regarded, followed by accountant and secretary in this order. These three occupations were chosen for a number of reasons. First, these jobs are classic white-collar jobs that allow moderate, 
steady careers. Turkish migrants in Germany often come from an underprivileged economic background. If they find a job in an office, it means that they have "arrived" in the mainstream of society. The other reasons for selecting office jobs are methodological. For female applicants, office jobs provide the researcher with a sufficiently large labor demand that guarantees that a reasonably large data set can be collected. Furthermore, for these jobs written applications are required rather than callins, which are common in blue-collar jobs. Finally, for the chosen jobs it was possible to create convincing application material and to provide the necessary attachments.

Application material. Following German norms, each application used in this experiment consisted of the following: a letter of application, a résumé, a photograph, a high school diploma (certifying university entry qualification) and a certificate of successful completion of an apprenticeship as an office clerk. The applications for chief accountants also included a certificate of advanced training in accounting. As has been argued before the large amount of information given in German applications makes statistical discrimination less likely. Examination results for different fields of study are provided in high school diplomas and certificates of apprenticeship. These are indicative of the cognitive abilities of a candidate. However, statistical discrimination may also be driven by employers' believes about personality traits of an applicant. In particular it may be that stereotypes ascribe migrants - in particular those who wear headscarves less favorable personal characteristics. To test whether unequal treatment is due to statistical discrimination with regard to personality, the following procedure was implemented: only a proportion of the applications had a reference letter from the company where the applicant was trained attached. ${ }^{13}$ This letter described not only the tasks the applicants had performed and the areas in which she was trained, it also characterized her achievements and her personality in a positive manner (in particular her fast learning, friendliness, dedication to learning, diligence, and promptness). This experimental design enabled testing whether migrants fare relatively better if they can signal positive personal characteristics. ${ }^{14}$

\footnotetext{
${ }^{13}$ In Germany, personnel managers usually advise applicants to attach reference letters by all means (even if they are not positive), arguing that incomplete applications would not be accepted. The results of this experiment show that this is not the case empirically.

${ }^{14}$ In the experiment, reference letters were identical for all applications. Of course in real life it is likely that discrimination also occurs with respect to job evaluation and that migrant workers who are equally productive as non-migrants receive less favorable reference letters.
} 
The documents were created in strict adherence to rules defined by the German Federal Anti-Discrimination Agency that legally cover testing procedures (Klose and Kühn 2010). Since only one application was sent to each firm, the different identities' applications were identical in every respect but name and photograph (as well as phone number and email address). The identities were assigned randomly to the job openings. At the time of the experiment, the fictitious applicants - Sandra Bauer and Meryem Ötztürk - were 27 years old. On average, Turkish migrants marry at a significantly younger age than German non-migrants. Without information to the contrary, employers would therefore expect the migrant to most likely be married and the non-migrant to be single. As marital status may affect employment chances, it came in handy that such information is typically provided in German applications. Within the experiment, all candidates were indicated to be single. Meryem Ötztürk thus signaled that she did not resemble the "average female with a Turkish background" and was committed to the labor market. This way the measure for discrimination did not become confounded with effects of marital status.

After receiving their high school diplomas (Abitur) and apprenticeships as office clerks, the applicants had 4 years of job experience as office clerks or accountants. Applicants for the job of a chief accountant had additionally successfully completed an advanced training course that formed the precondition for such a job. All applications included information on IT skills and foreign language abilities. They also stated that the applicants held driver's licenses. The applicants' hobbies were painting and sports, and they volunteered for a cultural center for which they did the bookkeeping.

Apart from the reasons discussed previously, statistical discrimination may also occur if employers are uncertain about the language proficiency of a migrant candidate or if there is uncertainty with regard to the transferability of schooling and training acquired abroad. ${ }^{15}$ These possible reasons for unequal treatment were eliminated in the current study: all candidates acquired all their schooling and training in Germany. As a result, it was beyond question that an applicant with a Turkish name would be fully proficient in the German language.

Procedure. For about one year, various popular online job portals were searched weekly for relevant job ads in the cities Berlin, Dresden, Frankfurt, Hamburg, Cologne, Munich

\footnotetext{
${ }^{15}$ Oreopoulos (2011) illustrated how foreign experience and foreign education is less valued by employers
} 
and Stuttgart. The application documents were combined in one electronic file that was sent to the companies by email. The applications provided full contact information: an address, an email address and a cell phone number which would forward to voicemail. This allowed companies to get in touch with the fictitious applicants. Applications were restricted to openings of full-time jobs whose basic requirements matched the profile of the fictitious candidates. Because only one application was sent in response to each ad, it was made sure that the vacancies included in the study were comparable. Each ad was carefully checked for its suitability and coded for how well it matched the standardized profile of the applicant. This information was used later as a control variable. If a personnel recruitment agency was involved in the selection process, the corresponding ad was omitted. To avoid detection, each company was contacted only once, even if it advertised multiple suitable jobs in the course of the experiment. All remaining companies that welcomed applications by email were contacted. Firms interested in an applicant could leave her a voicemail message or contact her by email or by regular mail. Invitations for interview and inquiries stating interest in the candidate were coded as positive responses (callback). If the applicant was invited for interview, the appointment was canceled within a day to avoid any inconvenience to the company.

\section{Results}

In the course of the experiment, a total of 1,474 applications were sent in response to job advertisements of companies located in Germany (for summary statistics see Table 1). The overall callback rates for the three identities are presented in Figure 2. The applicant with the German name - Sandra Bauer - was the most successful. She received positive feedback from $18.8 \%$ of all companies she applied to, followed by the applicant with the Turkish name (Meryem Öztürk) without headscarf, who was contacted by $13.5 \%$ of the companies. This difference is statistically significant $(\mathrm{t}=2.2633, \mathrm{p}=0.012$, one-sided $\mathrm{t}-$ test). As hypothesized, the applicant with the Turkish name who wore the headscarf fared the worst - she received positive feedback from only $4.2 \%$ of all companies contacted. The difference to both other identities is strongly significant (Ms. Öztürk with headscarf versus Ms. Bauer: $\mathrm{t}=7.3975, \mathrm{p}=0.000$, one-sided; Ms. Öztürk with headscarf versus Ms. Öztürk without headscarf: $\mathrm{t}=5.2395, \mathrm{p}=0.000$, one-sided). This result implies, that the candidate with the headscarf had to send 4.5 times as many applications as an 
identical applicant with a German name and no headscarf to receive the same number of callbacks for interview. This suggests that there is discrimination against female migrants - particularly if they wear a headscarf.

While callback rates differed between jobs (accountants are in higher demand than secretaries), discrimination was always highest against Meryem Öztürk when she was wearing a headscarf (see Table 2). However, as the relative callback rates ("ratio") illustrate, some differences in the extent of her disadvantage emerged across occupations. In the profession of chief accountant, Meryem Öztürk with a headscarf had to send almost 7.6 times as many applications as Sandra Bauer to receive an invitation for interview. The respective number for secretaries is "only" 3.5. That the level of discrimination was highest in the profession of chief accountant is remarkable because within the experiment chief accountant was the occupation with the highest qualifications necessary. It is often assumed that discrimination decreases with increasing level of education. However, wearing a headscarf may be considered even more inappropriate for positions with higher occupational status. ${ }^{16}$

Table 3 illustrates the callback rates at the city level. Discrimination against the applicant wearing a headscarf was everywhere significant at the 5\% level (except in Dresden, where hardly any relevant job openings were available); discrimination against the migrant without headscarf was significant only in Berlin.

Probabilities of a callback. A linear probability model was estimated to examine the probability of a positive callback more thoroughly. Since applications were sent to different firms, differences in invitation rates may have been due to differences in firm or job characteristics of the positions rather than discrimination, even though ads had been carefully checked for comparability. To account for such potential differences, a number of characteristics of job vacancies and the corresponding firms were subsequently controlled for. For example, applications in particular cities, sectors, or months may be systematically more successful. Also, only a fraction of applications included a reference letter. Employers may consider application packages that include a reference letter more complete and treat them more favorably. The results of the linear

\footnotetext{
${ }^{16}$ The result is also at odds with the notion that there is less discrimination when recruitment is difficult (Baert et al. 2015). Following Becker (1971) one would assume that discrimination can only occur if employers have a wide choice of potential workers to choose from. The high callback rates for accountants and chief accountants indicate that positions in these occupations are more difficult to fill than those of secretaries, yet discrimination against women who wear headscarves is not reduced in these occupations, on the contrary.
} 
probability model are presented in Table 4. The different specifications incrementally include the following control variables: occupational dummies (chief accountant, accountant and secretary), city dummies (Berlin, Dresden, Frankfurt, Hamburg, Cologne, Munich and Stuttgart), sector dummies (trade, public services, manufacturing and services), time dummies (in quarters), the attachment of a reference letter (yes/no), variables concerning size and internationality of a company ("firm characteristics") and a number of job characteristics that were derived from the requirements stated in the job advertisement - more specifically, whether the job required a special qualification that the standardized profile did not have ("special qualification requirement", SQR), or whether the job involved team and/or customer contact.

The results in Table 4 demonstrate that the effects found for the different identities are robust to adding these control variables. Hence, the unfavorable treatment of both job applicants with Turkish names cannot be explained by particular characteristics of either the specific firms or the jobs these women applied to in the randomized application design. In comparison to the German applicant, the bareheaded applicant with the Turkish name (Öztürk) was consistently by 5-6 percentage points less successful, while the migrant applicant who also wore a headscarf was even 15 percentage points less likely to receive a callback for interview. A test for the equality of coefficients shows that the differences between coefficients are highly significant (at the $1 \%$ level). Interestingly, even though the inclusion of a reference letter is often considered mandatory in Germany, the results show that its attachment does not generally lead to a positive effect. In the current setting, this may be due to the fact that these letters were constructed to give a positive but not an excellent impression. Also, if a job ad required an unusual qualification (SQR) that the applicant did not have, this did not reduce her callback rate on a significant level. The reason is probably that the fake applicants held typical qualifications for a particular position. If they did not have a special qualification, only few others would.

This study also tested a set of hypotheses concerning the reasons for unequal treatment. As previously pointed out, unequal treatment may be due to statistical discrimination. In this experiment, application materials provided employers with a vast amount of information concerning the qualifications of an applicant rendering statistical discrimination less likely in that respect. However, Muslim migrants may also suffer from statistical discrimination if they are ascribed personality traits that are deemed less productive in the job. To test this, a written reference from a previous employer was 
attached to a proportion of the applications. It described the applicant and her personality in favorable terms. If statistical discrimination occurs due to incomplete information regarding personality, attaching an identical reference letter should help migrants more than non-migrants, as negative beliefs about migrants are counteracted by positive characterizations.

Another reason for discrimination was proposed by Becker (1971). He argued that not only employers, but also customers and coworkers may hold discriminatory preferences. If customers and coworkers do not accept migrant workers, these cannot become fully productive and are less profitable to an employer. To test this hypothesis, the variable "team or customer contact" (TCC) was created that captures whether a job advertisement mentioned that such interaction was required at the job. It is also possible that larger firms discriminate less because they follow a more standardized, and therefore more objective, evaluation process than small companies (Kaas and Manger 2012). For this reason, in the present study the dummy variable "small firm" measures whether a firm has 1-20 employees. Companies that operate at an international level may also behave differently towards migrant applicants because they may be more familiar with diverse groups of people. This was examined via the dummy "international firm". Further, discrimination may be triggered by employers' beliefs that migrants are less proficient in the German language. The variable "German" measures whether a job ad emphasizes that proficiency in German is required for the job. In this experiment, fluency in German was signaled for all applicants by schooling and training received in Germany. Their callback rates should therefore have been unaffected by German language requirements. However, employers may use statements regarding German proficiency in job ads as subtle cues against migrant employees in general, irrespective of their language skills. Whether this is really the case was tested empirically. Conversely, some companies may actively seek migrant workers. Some firms explicitly asked for cross-cultural competence in their job advertisements or signaled that they are an intercultural team (this is captured by the dummy variable "interculturalism"). In such cases, discrimination may be reduced. Finally, some job advertisements mentioned that a neat appearance was required for the job ("appearance"). If conventional looks are of great importance for a certain job, firms may be particularly unwilling to hire a migrant woman with a headscarf.

To test these hypotheses, the linear probability model was extended to cover not only the full set of control variables (now also including "German", "Interculturalism" 
and "Appearance"), but also the interaction of each control variable with the variable "Öztürk" and with "Öztürk with headscarf". The results are presented in Table 5. The interaction effects illustrate which variables affect migrants differently than natives, and therefore help to identify reasons for differential treatment. As can be seen from Table 5, few interaction effects are significant at conventional levels. As mentioned above, Meryem Öztürk with a headscarf was discriminated to a greater degree in the occupations accountant and chief accountant. Else, only the attachment of a positive reference letter increased the migrants' relative invitation rates. This suggests that some prejudice is indeed at work when no references are provided. Interestingly, the reason why this effect occurred in this experiment was not that the migrant improved her absolute chances by attaching a reference letter, but that the non-migrant applicant reduced hers. This is probably the case because the letter described the applicant as good but not excellent, which may be less than what is expected from a non-migrant. Without reference letters, the non-migrant therefore benefits from positive stereotypes (positive statistical discrimination), while attaching them makes no difference to the migrant. Small firms may discriminate more, but these effects are - at best - significant at the $10 \%$ level. No effects were found concerning special qualification requirements (SQR), team or customer contact (TCC), internationality of a company, and German language requirements. The hypothesis that firms which expect a "neat appearance" from their applicants discriminate more against the headscarf than others was not confirmed. A marked effect, though, was identified for firms that asked for cross-cultural competence or signaled that they were an intercultural team, even if this effect is significant only at the $10 \%$ level and only for Ms. Öztürk with a headscarf. It indicates that, everything else being equal, Meryem Öztürk with a headscarf increases her relative callback chances by 37-39 percentage points if she applies to such a firm. Note, however, that only few firms fall into this category (about $2 \%$ ).

\section{Discussion}

A heated debate is being led in the West about the apparently inferior position of women in Muslim (migrant) culture. However, little discussion takes place about how Muslim women are actually treated by the Western majority population. To test discrimination of Western employers against Muslim migrant women, this study investigated employment opportunities of female office workers in Germany by sending identical applications to 
firms that differed only in the applicants' names and photographs. The results show that Turkish migrants (signaled by a Turkish name) are discriminated against at a significant level, in particular when their photograph shows them wearing a Muslim headscarf. Everything else equal, a female with a Turkish name who wears a headscarf has to send 4.5 times as many applications as an applicant with a German name and no headscarf to receive the same number of callbacks for interview. This level of discrimination is one of the highest that has been measured in the experimental discrimination literature (Hofer et al. 2013), and it is even higher for chief accountants and accountants. This massive rejection of the headscarf is all the more remarkable given the very modern and progressive binding used in the current experimental setting. That the headscarf shown in the application photograph did not cover the applicant's throat signaled that she is not particularly strict with respect to her religion. This should have minimized the level of discrimination measured. Discrimination is likely to be even higher against a more traditional binding of the headscarf.

It is often assumed that the unfavorable labor market position of Muslim migrant women is the result of a lack of education, job experience or dedication to the labor market. However, in this experiment, the migrant women had the exact same qualification as the woman without migration history. Since schooling and job experience were identical to that of a non-migrant, it must have been obvious to the employers that the candidates were fluent in German. The many years of job experience signaled that they were eager to work.

In Germany, applications indicate the applicant's family status: all applicants in this experiment identified as single, signaling to potential employers that they had no family obligations. As the applications were comprehensive and provided many details (e.g., school grades and further training), the companies had a vast amount of information available to base their decision on. When applications also included reference letters that described the candidate in positive but not excellent terms, this reduced the level of discrimination. In this case, non-migrants did not benefit from positive stereotypes (positive statistical discrimination). In the experimental résumé, applicants were not given any spells of unemployment. Given the high level of discrimination against the woman with a headscarf, for her to hold such a résumé is actually unlikely unless she is substantially more able than the native. This suggests that discrimination is still underestimated in this experiment. 
Critics may argue that in this study the woman wearing the headscarf is not discriminated against because of the headscarf per se but because headscarves are considered inappropriate for application photographs. However, as Unkelbach et al. (2010, p. 382) stated, it does not matter whether discrimination is due to wearing headscarves in application photos not being considered business savvy or due to a distaste for headscarves: "The hijab disadvantages the wearer, whether the underlying processes are explicit (i.e., it is directly used to discriminate between applicants) or implicit (i.e., it activates negative stereotypes that influence decisions about applicants.)" ${ }^{17}$ In any case, attaching a photograph with a headscarf is not an uncommon practice. Syed and Pio (2010) reported that even in countries where photos are not commonly included in job applications, some headscarf wearing women deliberately attach their photograph to screen for non-discriminatory companies. Thus, they avoid wasting time meeting employers who, on principle, do not hire women who wear headscarves.

To examine why and when discrimination occurs, the effects of various firm and job characteristics were examined in this study. For example, it may be that small firms discriminate more or that international firms discriminate less. However, firm and job characteristics helped little to explain unequal treatment. The dislike for migrant applicants identified by this study may be explained by Social Identity Theory. To German employers, migrants represent an outgroup, which may lead to their rejection. Social Identity Theory predicts that women wearing the headscarf should be particularly negatively affected, as they signal a strong identification with the Muslim outgroup and may be perceived as particularly distant. Exactly this was found in this study. Callback rates for women who wear the headscarf are meager, even in comparison to bareheaded migrant women. Obviously, women wearing headscarves are a social group that experiences particular rejection in the German labor market.

While in the late $20^{\text {th }}$ century Muslim migrants to Germany came mainly from Turkey, Germany is currently facing a large influx of Muslim migrants that are predominantly from Syria. If integration is to succeed, the existing discrimination in the labor market needs to be eliminated.

\footnotetext{
${ }^{17}$ Tilcsik (2011) and Weichselbaumer (2015) have argued similarly with respect to gays and lesbians who out themselves by mentioning volunteer work at a gay and lesbian organization in their résumés. If an applicant is treated unfavorably because an employer believes they violated a social norm by mentioning volunteer work at a gay and lesbian organization, this is still discrimination based on sexual orientation. Mentioning such an engagement can only be considered embarrassing, if same-sex orientation itself is regarded objectionable.
} 


\section{References}

Acquisti, Alessandro, and Christina M. Fong. 2015. "An Experiment in Hiring Discrimination via Online Social Networks." Carnegie Mellon University Working Paper.

ADC-RI. American-Arab Anti-Discrimination Committee Research. 2008. Report of Hate Crimes and Discrimination against Arab-Americans: 2003-2007. Washington.

Adida, Claire L, David D Laitin, and Marie-Anne Valfort. 2010. "Identifying Barriers to Muslim Integration in France." Proceedings of the National Academy of Sciences 107(52): 22384-90.

Ahmed, Ali M. 2010. "Muslim Discrimination: Evidence from Two Lost-Letter Experiments." Journal of Applied Social Psychology 40(4): 888-98.

Ahmed, Ali M., Lina Andersson, and Mats Hammarstedt. 2013. "Are Gay Men and Lesbians Discriminated against in the Hiring Process?" Southern Economic Journal 79(3): 565-85.

Akerlof, George A., and Rachel E. Kranton. 2000. "Economics and Identity." Quarterly Journal of Economics 115(3): 715-53.

Arrow, Kenneth. 1973. "The Theory of Discrimination." In Discrimination in Labor Markets, eds. Orley Ashenfelter and Albert Rees. Princeton: Princeton University Press, 3-33.

Baert, Stijn, Bart Cockx, Niels Gheyle, and Cora Vandamme. 2015. "Is There Less Discrimination in Occupations Where Recruitment Is Difficult?" Industrial and Labor Relations Review 68(3): 467-500.

Becker, Gary S. 1971. The Economics of Discrimination. Second Edi. Chicago: University of Chicago Press.

Bertelsmann Stiftung. 2015. Religion Monitor. Understanding Common Ground. Special Study of Islam, 2015. An Overview of the Most Important Findings. Gütersloh.

Bertrand, Marianne, and Esther Duflo. 2016. "Field Experiments on Discrimination." NBER Working Paper (22014).

Bertrand, Marianne, and Sendhil Mullainathan. 2004. "Are Emily and Greg More Employable Than Lakisha and Jamal? A Field Experiment on Labor Market Discrimination." American Economic Review 94(4): 991-1013.

Blank, Rebecca M., Marilyn Dabady, and Constance F. Citro. 2004. Social Sciences Measuring Racial Discrimination: Panel on Methods for Assessing Discrimination. Washington: National Academies Press.

Byng, Michelle D. 2010. "Symbolically Muslim: Media, Hijab, and the West." Critical Sociology 36(1): 109-29.

Derous, Eva, Hannah-Hanh Nguyen, and Ann Marie Ryan. 2009. "Hiring Discrimination against Arab Minorities: Interactions between Prejudice and Job Characteristics." Human Performance 22(4): 297-320.

FBI. Federal Bureau of Investigation. "Hate Crime Statistics (Various Years)." https://www.fbi.gov/about-us/cjis/ucr/hate-crime/ (May 8, 2015).

Fershtman, Chaim, and Uri Gneezy. 2001. "Discrimination in a Segmented Society: An Experimental Approach." The Quarterly Journal of Economics 116(1): 351-77.

Ghumman, Sonia, and Linda Jackson. 2008. "Between a Cross and a Hard Place: Religious Identifiers and Employability." Journal of Workplace Rights 13(3): 25979.

Ghumman, Sonia, and Linda Jackson. 2010. "The Downside of Religious Attire: The Muslim Headscarf and Expectations of Obtaining Employment." Journal of 
Organizational Behavior 31(1): 4-23.

Ghumman, Sonia, and Ann Marie Ryan. 2013. "Not Welcome Here: Discrimination towards Women Who Wear the Muslim Headscarf." Human Relations 66(5): 67198.

Heckman, James J. 1998. "Detecting Discrimination.” Journal of Economic Perspectives 12(2): 101-16.

Heckman, James J., and Peter Siegelman. 1993. "The Urban Institute Audit Studies: Their Methods and Findings." In Clear and Convincing Evidence: Measurment of Discrimination in America, eds. Michael Fix and Raymond Struyk. Washington: Urban Institute Press, 187-258.

Helbling, Marc. 2014. "Opposing Muslims and the Muslim Headscarf in Western Europe." European Sociological Review 30(2): 242-57.

Hofer, Helmut, Gerlinde Titelbach, Doris Weichselbaumer, and Rudolf Winter-Ebmer. 2013. Diskriminierung von MigrantInnen Am Österreichischen Arbeitsmarkt. IHS Projektbericht. Wien: Bundesministerium für Arbeit, Soziales und Konsumentenschutz.

Kaas, Leo, and Christian Manger. 2012. "Ethnic Discrimination in Germany's Labour Market: A Field Experiment." German Economic Review 13(1): 1-20.

King, Eden B., and Afra S. Ahmad. 2010. "An Experimental Field Study of Interpersonal Discrimination toward Muslim Job Applicants." Personnel Psychology 63(4): 881-906.

Klose, Alexander, and Kerstin Kühn. 2010. Die Anwendbarkeit von Testing-Verfahren Im Rahmen Der Beweislast, § 22 Allgemeines Gleichbehandlungsgesetz. Berlin: Antidiskriminierungsstelle des Bundes.

List, John A. 2011. "Why Economists Should Conduct Field Experiments and 14 Tips for Pulling One off." Journal of Economic Perspectives 25(3): 3-16.

López Bóo, Florencia, Martín A. Rossi, and Sergio S. Urzúa. 2013. "The Labor Market Return to an Attractive Face: Evidence from a Field Experiment." Economics Letters 118(1): 170-72.

Neumark, David. forthcoming. "Experimental Research on Labor Market Discrimination." Journal of Economic Literature.

Oreopoulos, Philip. 2011. "Why Do Skilled Immigrants Struggle in the Labor Market? A Field Experiment with Thirteen Thousand Resumes." American Economic Journal: Economic Policy 3(4): 148-71.

Phelps, Edmund S. 1972. "The Statistical Theory of Racism and Sexism." The American Economic Review 62(4): 659-61.

Pierné, Guillaume. 2013. "Hiring Discrimination Based on National Origin and Religious Closeness: Results from a Field Experiment in the Paris Area." IZA Journal of Labor Economics 2(4): 1-15.

Rich, Judith. 2014. "What Do Field Experiments of Discrimination in Markets Tell Us? A Meta Analysis of Studies Conducted since 2000." IZA Discussion Paper (8584).

Rooth, Dan-Olof. 2009. "Obesity, Attractiveness, and Differential Treatment in Hiring. A Field Experiment." The Journal of Human Resources 44(3): 710-35.

Ruffle, Bradley J, and Ze'ev Shtudiner. 2015. "Are Good-Looking People More Employable?" Management Science 61(8): 1760-76.

Shadid, Wasif, and Pieter Sjoerd van Koningsveld. 2005. "Muslim Dress in Europe: Debates on the Headscarf." Journal of Islamic Studies 16(1): 35-61.

Spielhaus, Riem. 2013. Muslime in Der Statistik. Wer Ist Muslim Und Wenn Ja Wie Viele? Gutachten Im Auftrag Des Mediendienst Integration. Berlin: Mediendienst Integration. 
Syed, Jawad, and Edwina Pio. 2010. "Veiled Diversity? Workplace Experiences of Muslim Women in Australia." Asia Pacific Journal of Management 27(1): 115-37.

Tajfel, Henri. 1981. Human Groups and Social Categories: Studies in Social Psychology. Cambridge: Cambridge University Press.

Tilcsik, András. 2011. "Pride and Prejudice: Employment Discrimination against Openly Gay Men in the United States 1." American Journal of Sociology 117(2): 586-626.

Unkelbach, Christian, Joseph P. Forgas, and Thomas F. Denson. 2008. "The Turban Effect: The Influence of Muslim Headgear and Induced Affect on Aggressive Responses in the Shooter Bias Paradigm." Journal of Experimental Social Psychology 44(5): 1409-13.

Unkelbach, Christian, Hella Schneider, Kai Gode, and Miriam Senft. 2010. "A Turban Effect, Too: Selection Biases against Women Wearing Muslim Headscarves." Social Psychological and Personality Science 1(4): 378-83.

Van der Noll, Jolanda. 2010. "Public Support for a Ban on Headscarves: A CrossNational Perspective." International Journal of Conflict and Violence 4(2): 191203.

Weichselbaumer, Doris. 2015. "Testing for Discrimination against Lesbians of Different Marital Status: A Field Experiment." Industrial Relations 54(1): 131-61.

Weichselbaumer, Doris. (forthcoming) "Discrimination against Migrant Job Applicants in Austria: An Experimental Study." German Economic Review.

World Values Survey. 2006. "Data." http://www.worldvaluessurvey.org/ (May 6, 2015).

Zschirnt, Eva, and Didier Ruedin. 2016. "Ethnic Discrimination in Hiring Decisions: A Meta-Analysis of Correspondence Tests 1990-2015." Journal of Ethnic and Migration Studies 42(7): 1115-34. 
Figures

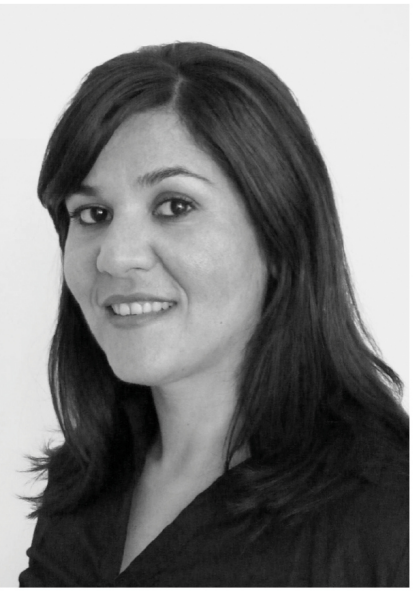

Sandra Bauer

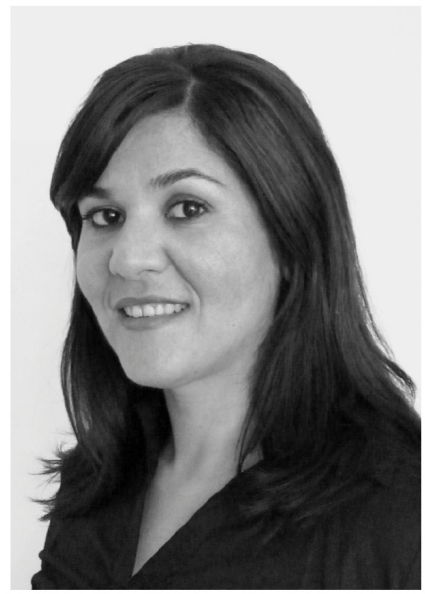

Meryem Öztürk

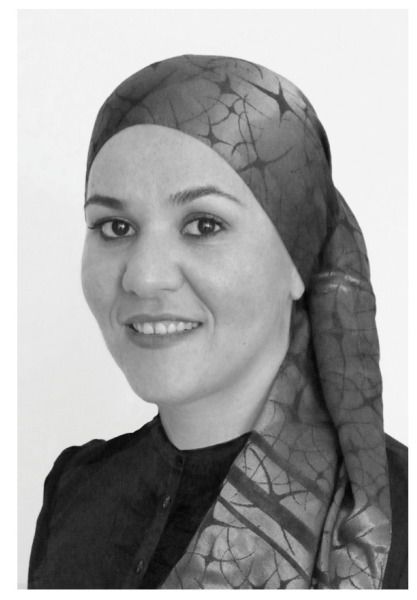

Meryem Öztürk

Fig. 1. Names and photographs, indicators for identity

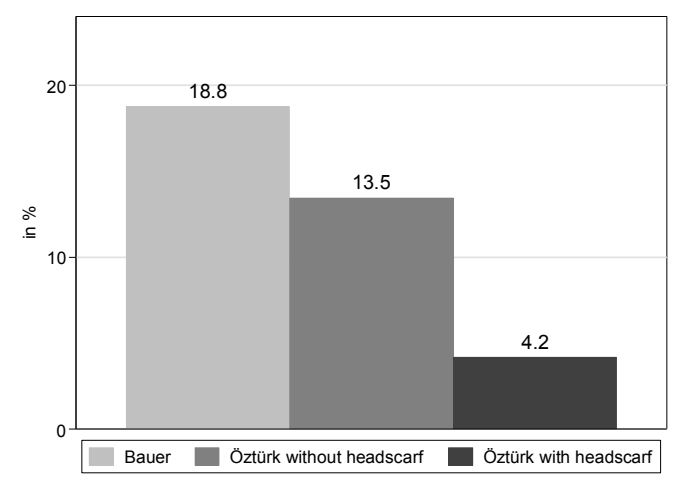

Fig. 2. Callbacks by identity 


\section{Tables}

Table 1: Summary statistics

\begin{tabular}{lccccc}
\hline Variable & Obs. & Mean & Std. Dev. & Min & Max \\
\hline Callback & 1474 & 0,12 & 0,32 & 0 & 1 \\
Bauer & 1474 & 0,32 & 0,47 & 0 & 1 \\
Öztürk & 1474 & 0,34 & 0,47 & 0 & 1 \\
Öztürk with headscarf & 1474 & 0,34 & 0,47 & 0 & 1 \\
Secretary & 1474 & 0,60 & 0,49 & 0 & 1 \\
Accountant & 1474 & 0,24 & 0,43 & 0 & 1 \\
Chief accountant & 1474 & 0,17 & 0,37 & 0 & 1 \\
Small firm & 1467 & 0,10 & 0,30 & 0 & 1 \\
International firm & 1468 & 0,54 & 0,50 & 0 & 1 \\
Reference letter & 1474 & 0,32 & 0,47 & 0 & 1 \\
Special qualification requirements & 1474 & 0,17 & 0,38 & 0 & 1 \\
German proficiency required & 1474 & 0,24 & 0,43 & 0 & 1 \\
Team and/or customer contact & 1474 & 0,65 & 0,48 & 0 & 1 \\
Interculturalism & 1474 & 0,02 & 0,15 & 0 & 1 \\
Appearance & 1474 & 0,03 & 0,18 & 0 & 1 \\
Berlin & 1474 & 0,11 & 0,31 & 0 & 1 \\
Dresden & 1474 & 0,01 & 0,12 & 0 & 1 \\
Frankfurt & 1474 & 0,16 & 0,37 & 0 & 1 \\
Hamburg & 1474 & 0,23 & 0,42 & 0 & 1 \\
Cologne & 1474 & 0,18 & 0,39 & 0 & 1 \\
Munich & 1474 & 0,20 & 0,40 & 0 & 1 \\
Stuttgart & 1474 & 0,10 & 0,30 & 0 & 1 \\
Branche dummy: Services & 1474 & 0,65 & 0,48 & 0 & 1 \\
Branche dummy: Trade & 1474 & 0,19 & 0,40 & 0 & 1 \\
Branche dummy: Public services & 1474 & 0,04 & 0,20 & 0 & 1 \\
Branche dummy: Production & 1474 & 0,12 & 0,32 & 0 & 1 \\
\hline & & & & & \\
& & & & & \\
& & & & &
\end{tabular}


Table 2: Callback rates and relative callback rates by occupation

\begin{tabular}{|c|c|c|c|c|c|c|c|c|}
\hline & \multicolumn{2}{|c|}{ All } & \multicolumn{2}{|c|}{ Chief accountant } & \multicolumn{2}{|c|}{ Accountant } & \multicolumn{2}{|c|}{ Secretary } \\
\hline & $\begin{array}{r}\text { Callback } \\
\text { rate }\end{array}$ & Ratio ${ }^{\dagger}$ & $\begin{array}{r}\text { Callback } \\
\text { rate }\end{array}$ & Ratio $\dagger$ & $\begin{array}{r}\text { Callback } \\
\text { rate }\end{array}$ & Ratio $\dagger$ & $\begin{array}{r}\text { Callback } \\
\text { rate }\end{array}$ & Ratio $†$ \\
\hline German name (bareheaded) & $\begin{array}{r}18.8 \% \\
(\mathrm{~N}=474)\end{array}$ & & $\begin{array}{r}27.3 \% \\
(\mathrm{~N}=77)\end{array}$ & & $\begin{array}{r}29 \% \\
(\mathrm{~N}=107)\end{array}$ & & $\begin{array}{r}12.8 \% \\
(\mathrm{~N}=290)\end{array}$ & \\
\hline Turkish name (bareheaded) & $\begin{array}{r}13.5 \% \\
(\mathrm{~N}=498)\end{array}$ & $1.39 * *$ & $\begin{array}{r}19 \% \\
(\mathrm{~N}=84)\end{array}$ & 1.44 & $\begin{array}{r}19 \% \\
(\mathrm{~N}=121)\end{array}$ & $1.53 *$ & $\begin{array}{r}9.6 \% \\
(\mathrm{~N}=293)\end{array}$ & 1.33 \\
\hline Turkish name with headscarf & $\begin{array}{r}4.2 \% \\
(\mathrm{~N}=502)\end{array}$ & $4.48 * * *$ & $\begin{array}{r}3.6 \% \\
(\mathrm{~N}=83)\end{array}$ & $7.58 * * *$ & $\begin{array}{r}5.8 \% \\
(\mathrm{~N}=121)\end{array}$ & $5.00 * * *$ & $\begin{array}{r}3.7 \% \\
(\mathrm{~N}=298)\end{array}$ & $3.46^{* * *}$ \\
\hline
\end{tabular}

Note: $\dagger$ the ratio (or "relative callback rate") is defined as follows: callback rate German name/callback rate Turkish name (bareheaded or with headscarf).

$* * * \mathrm{p}<0.01,{ }^{* *} \mathrm{p}<0.05, * \mathrm{p}<0.1$

Table 3: Callback rates by city

\begin{tabular}{|l|c|c|c|c|ccc|}
\hline & 1. Bauer & 2. Öztürk & 3. Ö. headscarf & & $(1)$ & $(2)$ & $(3)$ \\
\cline { 2 - 7 } & invit.rate & invit.rate & invit.rate & $\mathrm{N}$ & \multicolumn{2}{|c|}{ sig. 1- sig. 1- sig. 2- } \\
& $24.1 \%$ & $11.1 \%$ & $5.4 \%$ & 163 & $* *$ & $* * *$ & 3 \\
\hline Berlin & $20 \%$ & $0 \%$ & $0 \%$ & 21 & & $*$ & - \\
Dresden & $22.4 \%$ & $15.4 \%$ & $4.5 \%$ & 242 & $* * *$ & $* * *$ \\
Frankfurt & $13.9 \%$ & $15.7 \%$ & $3.6 \%$ & 339 & $* * *$ & $* * *$ \\
Hamburg & $14 \%$ & $11.6 \%$ & $2.5 \%$ & 268 & $* * *$ & $* *$ \\
Cologne & $21.3 \%$ & $14.1 \%$ & $8.2 \%$ & 293 & $*$ & $* * *$ & $*$ \\
Munich & $21.4 \%$ & $10.6 \%$ & $0 \%$ & 148 & $*$ & $* * *$ & $* * *$ \\
Stuttgart & &
\end{tabular}

Note: Results from a t-test: $* * * \mathrm{p}<0.01,{ }^{* *} \mathrm{p}<0.05,{ }^{*} \mathrm{p}<0.1$

Column (1) compares the callback rates of Ms. Bauer and Ms. Öztürk (without headscarf), (2) of Ms. Bauer and Ms. Öztürk with a headscarf, and (3) of Ms. Öztürk without and with a headscarf. 
Table 4: Probability of a callback (Linear Probability Model)

\begin{tabular}{|c|c|c|c|c|}
\hline Variables & $\begin{array}{c}(1) \\
\text { Callback }\end{array}$ & $\begin{array}{c}(2) \\
\text { Callback }\end{array}$ & $\begin{array}{c}(3) \\
\text { Callback }\end{array}$ & $\begin{array}{c}(4) \\
\text { Callback }\end{array}$ \\
\hline Öztürk & $\begin{array}{c}-0.053^{* * *} \\
(-2.59)\end{array}$ & $\begin{array}{c}-0.054 * * * \\
(-2.63)\end{array}$ & $\begin{array}{c}-0.054 * * * \\
(-2.64)\end{array}$ & $\begin{array}{c}-0.057 * * * \\
(-2.79)\end{array}$ \\
\hline Öztürk with headscarf & $\begin{array}{c}-0.146^{* * *} \\
(-7.13)\end{array}$ & $\begin{array}{c}-0.147 * * * \\
(-7.24)\end{array}$ & $\begin{array}{c}-0.148 * * * \\
(-7.24)\end{array}$ & $\begin{array}{c}-0.149 * * * \\
(-7.29)\end{array}$ \\
\hline Chief accountant & & $\begin{array}{c}0.074 * * * \\
(3.19)\end{array}$ & $\begin{array}{l}0.075^{* * *} \\
(3.20)\end{array}$ & $\begin{array}{c}0.077 * * * \\
(3.28)\end{array}$ \\
\hline Accountant & & $\begin{array}{c}0.090^{* * *} \\
(4.43)\end{array}$ & $\begin{array}{c}0.090 * * * \\
(4.44)\end{array}$ & $\begin{array}{c}0.088^{* * *} \\
(4.30)\end{array}$ \\
\hline Reference letter & & & $\begin{array}{l}-0.012 \\
(-0.51)\end{array}$ & $\begin{array}{l}-0.012 \\
(-0.51)\end{array}$ \\
\hline Job characteristics & & & & \\
\hline $\begin{array}{l}\text { Special qualification requirements } \\
(\mathrm{SQR})(\text { Yes }=1)\end{array}$ & & & & $\begin{array}{l}-0.031 \\
(-1.37)\end{array}$ \\
\hline Team and/or customer contact (TCC) & & & & 0.004 \\
\hline$(\mathrm{Yes}=1)$ & & & & $(0.21)$ \\
\hline Firm characteristics & & & & \\
\hline Small firm $($ Yes $=1)$ & & & & $\begin{array}{l}0.004 \\
(0.15)\end{array}$ \\
\hline International firm $($ Yes $=1)$ & & & & $\begin{array}{l}0.001 \\
(0.08)\end{array}$ \\
\hline Time dummies & no & yes & yes & yes \\
\hline City dummies & no & yes & yes & yes \\
\hline Sector dummies & no & yes & yes & yes \\
\hline Constant & $\begin{array}{c}0.188 * * * \\
(12.78)\end{array}$ & $\begin{array}{c}0.129 * * * \\
(3.84)\end{array}$ & $\begin{array}{c}0.136^{* * *} \\
(3.77)\end{array}$ & $\begin{array}{c}0.139 * * * \\
(3.58)\end{array}$ \\
\hline No. of observations & 1,474 & 1,474 & 1,474 & 1,467 \\
\hline $\mathrm{R}^{2}$ & 0.034 & 0.061 & 0.062 & 0.063 \\
\hline Adjusted $\mathrm{R}^{2}$ & 0.033 & 0.051 & 0.051 & 0.049 \\
\hline
\end{tabular}

Note: t-statistics in parentheses, ${ }^{* * *} \mathrm{p}<0.01,{ }^{* *} \mathrm{p}<0.05, * \mathrm{p}<0.1$

The dependent variable is a dummy for receiving a positive callback. The reference category for identity: Bauer; for occupation: secretary. 
Table 5: Reasons for unequal treatment (Linear Probability Model)

\begin{tabular}{|c|c|c|c|c|c|}
\hline Variables & $\begin{array}{c}(0) \\
\text { Callback }\end{array}$ & $\begin{array}{c}(1) \\
\text { Callback }\end{array}$ & $\begin{array}{c}(2) \\
\text { Callback }\end{array}$ & $\begin{array}{c}(3) \\
\text { Callback }\end{array}$ & $\begin{array}{c}(4) \\
\text { Callback }\end{array}$ \\
\hline Öztürk & $\begin{array}{c}-0.060 * * * \\
(-2.91)\end{array}$ & $\begin{array}{c}-0.093 * * * \\
(-3.74)\end{array}$ & $\begin{array}{c}-0.072 * * \\
(-2.38)\end{array}$ & $\begin{array}{c}-0.088^{*} \\
(-1.84)\end{array}$ & $\begin{array}{l}-0.053 \\
(-1.01)\end{array}$ \\
\hline Öztürk with headscarf & $\begin{array}{c}-0.153 * * * \\
(-7.45)\end{array}$ & $\begin{array}{c}-0.179 * * * \\
(-7.15)\end{array}$ & $\begin{array}{c}-0.123 * * * \\
(-4.07)\end{array}$ & $\begin{array}{c}-0.183 * * * \\
(-3.70)\end{array}$ & $\begin{array}{c}-0.114 * * \\
(-2.13)\end{array}$ \\
\hline Chief accountant & $\begin{array}{c}0.078 * * * \\
(3.28)\end{array}$ & $\begin{array}{c}0.078 * * * \\
(3.26)\end{array}$ & $\begin{array}{c}0.143 * * * \\
(3.43)\end{array}$ & $\begin{array}{c}0.081^{* * *} \\
(3.38)\end{array}$ & $\begin{array}{c}0.161 * * * \\
(3.74)\end{array}$ \\
\hline Chief accountant*Öztürk & & & $\begin{array}{l}-0.047 \\
(-0.82)\end{array}$ & & $\begin{array}{l}-0.075 \\
(-1.28)\end{array}$ \\
\hline Chief accountant*Öztürk with headscarf & & & $\begin{array}{c}-0.144 * * \\
(-2.53)\end{array}$ & & $\begin{array}{c}-0.157 * * * \\
(-2.66)\end{array}$ \\
\hline Accountant & $\begin{array}{c}0.087 * * * \\
(4.14)\end{array}$ & $\begin{array}{c}0.086^{* * *} * \\
(4.09)\end{array}$ & $\begin{array}{c}0.151 * * * \\
(4.14)\end{array}$ & $\begin{array}{c}0.088^{* * *} \\
(4.18)\end{array}$ & $\begin{array}{c}0.164 * * * \\
(4.41)\end{array}$ \\
\hline Accountant*Öztürk & & & $\begin{array}{l}-0.057 \\
(-1.14)\end{array}$ & & $\begin{array}{l}-0.077 \\
(-1.49)\end{array}$ \\
\hline Accountant*Öztürk with headscarf & & & $\begin{array}{c}-0.133 * * * \\
(-2.69)\end{array}$ & & $\begin{array}{c}-0.145 * * * \\
(-2.82)\end{array}$ \\
\hline Reference letter & $\begin{array}{l}-0.010 \\
(-0.42)\end{array}$ & $\begin{array}{c}-0.072 * * \\
(-2.06)\end{array}$ & $\begin{array}{c}-0.067^{*} \\
(-1.94)\end{array}$ & $\begin{array}{c}-0.076^{* *} \\
(-2.17)\end{array}$ & $\begin{array}{c}-0.074 * * \\
(-2.11)\end{array}$ \\
\hline Reference letter*Öztürk & & $\begin{array}{c}0.103^{* *} \\
(2.35)\end{array}$ & $\begin{array}{c}0.099^{* *} \\
(2.25)\end{array}$ & $\begin{array}{c}0.110^{* *} \\
(2.47)\end{array}$ & $\begin{array}{c}0.109^{* *} \\
(2.44)\end{array}$ \\
\hline Reference letter*Öztürk with headscarf & & $\begin{array}{l}0.079 * \\
(1.81)\end{array}$ & $\begin{array}{l}0.076^{*} \\
(1.73)\end{array}$ & $\begin{array}{l}0.085^{*} \\
(1.89)\end{array}$ & $\begin{array}{l}0.082^{*} \\
(1.83)\end{array}$ \\
\hline $\begin{array}{l}\text { Special qualification requirements } \\
\text { (SQR) }\end{array}$ & $\begin{array}{l}-0.033 \\
(-1.47)\end{array}$ & $\begin{array}{l}-0.033 \\
(-1.47)\end{array}$ & $\begin{array}{l}-0.037 * \\
(-1.65)\end{array}$ & $\begin{array}{l}-0.065^{*} \\
(-1.72)\end{array}$ & $\begin{array}{l}-0.072 * \\
(-1.87)\end{array}$ \\
\hline SQR*Öztürk & & & & $\begin{array}{l}0.047 \\
(0.86)\end{array}$ & $\begin{array}{l}0.054 \\
(0.97)\end{array}$ \\
\hline SQR*Öztürk with headscarf & & & & $\begin{array}{l}0.057 \\
(1.06)\end{array}$ & $\begin{array}{l}0.054 \\
(1.00)\end{array}$ \\
\hline Team and/or customer contact (TCC) & $\begin{array}{l}0.004 \\
(0.21)\end{array}$ & $\begin{array}{l}0.003 \\
(0.18)\end{array}$ & $\begin{array}{l}0.004 \\
(0.20)\end{array}$ & $\begin{array}{l}-0.008 \\
(-0.27)\end{array}$ & $\begin{array}{l}-0.010 \\
(-0.34)\end{array}$ \\
\hline TCC*Öztürk & & & & $\begin{array}{l}0.031 \\
(0.72)\end{array}$ & $\begin{array}{l}0.033 \\
(0.77)\end{array}$ \\
\hline TCC $*$ Öztürk with headscarf & & & & $\begin{array}{l}-0.005 \\
(-0.11)\end{array}$ & $\begin{array}{l}0.000 \\
(0.01)\end{array}$ \\
\hline Small firm & $\begin{array}{l}0.007 \\
(0.25)\end{array}$ & $\begin{array}{l}0.009 \\
(0.31)\end{array}$ & $\begin{array}{l}0.013 \\
(0.45)\end{array}$ & $\begin{array}{l}0.086^{*} \\
(1.71)\end{array}$ & $\begin{array}{l}0.093^{*} \\
(1.86)\end{array}$ \\
\hline Small firm*Öztürk & & & & $\begin{array}{l}-0.114 \\
(-1.57)\end{array}$ & $\begin{array}{l}-0.120^{*} \\
(-1.66)\end{array}$ \\
\hline Small firm*Öztürk with headscarf & & & & $\begin{array}{l}-0.112 \\
(-1.63)\end{array}$ & $\begin{array}{l}-0.118^{*} \\
(-1.72)\end{array}$ \\
\hline
\end{tabular}




\begin{tabular}{|c|c|c|c|c|c|}
\hline International firm & $\begin{array}{l}-0.000 \\
(-0.01)\end{array}$ & $\begin{array}{l}0.001 \\
(0.03)\end{array}$ & $\begin{array}{l}0.001 \\
(0.06)\end{array}$ & $\begin{array}{l}0.010 \\
(0.31)\end{array}$ & $\begin{array}{l}0.010 \\
(0.32)\end{array}$ \\
\hline International firm*Öztürk & & & & $\begin{array}{l}-0.020 \\
(-0.47)\end{array}$ & $\begin{array}{l}-0.021 \\
(-0.49)\end{array}$ \\
\hline $\begin{array}{l}\text { International firm*Öztürk with } \\
\text { headscarf }\end{array}$ & & & & $\begin{array}{l}-0.006 \\
(-0.14)\end{array}$ & $\begin{array}{l}-0.006 \\
(-0.14)\end{array}$ \\
\hline German & $\begin{array}{l}-0.008 \\
(-0.39)\end{array}$ & $\begin{array}{l}-0.006 \\
(-0.29)\end{array}$ & $\begin{array}{l}-0.004 \\
(-0.20)\end{array}$ & $\begin{array}{l}0.013 \\
(0.34)\end{array}$ & $\begin{array}{l}0.037 \\
(0.98)\end{array}$ \\
\hline German*Öztürk & & & & $\begin{array}{l}-0.066 \\
(-1.34)\end{array}$ & $\begin{array}{l}-0.090^{*} \\
(-1.77)\end{array}$ \\
\hline German*Öztürk with headscarf & & & & $\begin{array}{l}0.020 \\
(0.41)\end{array}$ & $\begin{array}{l}-0.020 \\
(-0.39)\end{array}$ \\
\hline Interculturalism & $\begin{array}{c}0.134^{* *} \\
(2.40)\end{array}$ & $\begin{array}{c}0.131^{* *} \\
(2.37)\end{array}$ & $\begin{array}{c}0.135^{* *} \\
(2.44)\end{array}$ & $\begin{array}{l}-0.181 \\
(-0.97)\end{array}$ & $\begin{array}{l}-0.194 \\
(-1.04)\end{array}$ \\
\hline Interculturalism*Öztürk & & & & $\begin{array}{l}0.306 \\
(1.49)\end{array}$ & $\begin{array}{l}0.321 \\
(1.57)\end{array}$ \\
\hline Interculturalism*Öztürk with headscarf & & & & $\begin{array}{l}0.367^{*} \\
(1.81)\end{array}$ & $\begin{array}{l}0.390^{*} \\
(1.92)\end{array}$ \\
\hline Appearance & $\begin{array}{l}0.017 \\
(0.38)\end{array}$ & $\begin{array}{l}0.022 \\
(0.47)\end{array}$ & $\begin{array}{l}0.018 \\
(0.39)\end{array}$ & $\begin{array}{l}0.003 \\
(0.04)\end{array}$ & $\begin{array}{l}0.029 \\
(0.37)\end{array}$ \\
\hline Appearance*Öztürk & & & & $\begin{array}{l}0.007 \\
(0.05)\end{array}$ & $\begin{array}{l}-0.019 \\
(-0.15)\end{array}$ \\
\hline Appearance*Öztürk with headscarf & & & & $\begin{array}{l}0.036 \\
(0.35)\end{array}$ & $\begin{array}{l}-0.019 \\
(-0.18)\end{array}$ \\
\hline Time dummies & yes & yes & yes & yes & yes \\
\hline City dummies & yes & yes & yes & yes & yes \\
\hline Sector dummies & yes & yes & yes & yes & yes \\
\hline Constant & $\begin{array}{c}0.136^{* * *} \\
(3.45)\end{array}$ & $\begin{array}{c}0.153 * * * \\
(3.80)\end{array}$ & $\begin{array}{l}0.123 * * * \\
(2.94)\end{array}$ & $\begin{array}{c}0.153 * * * \\
(3.32)\end{array}$ & $\begin{array}{c}0.113^{* *} \\
(2.36)\end{array}$ \\
\hline No. of observations & 1,467 & 1,467 & 1,467 & 1,467 & 1,467 \\
\hline $\mathrm{R}^{2}$ & 0.067 & 0.071 & 0.078 & 0.079 & 0.087 \\
\hline Adjusted $\mathrm{R}^{2}$ & 0.051 & 0.054 & 0.059 & 0.054 & 0.059 \\
\hline
\end{tabular}

Note: t-statistics in parentheses, $* * * \mathrm{p}<0.01, * * \mathrm{p}<0.05, * \mathrm{p}<0.1$

The dependent variable is a dummy for receiving a positive callback. The reference category for identity: Bauer; for occupation: secretary. 